IRSTI 02.71

\author{
Yasar Aydinli \\ Uludag University, Turkey, Busra, e-mail: yasaraydinli@hotmail.com
}

\title{
FARABI AND THE MODERN WORLD
}

The essay discusses the ethical and philosophical views of the great thinker and philosopher alFarabi. The philosophical system created by al-Farabi deals with the main problems related to questions of God, the universe and man, as well as the place of man in the universe. The formation of philosophical thinking of al-Farabi was influenced by ancient Greek philosophy, in particular, the works of Aristotle. AlFarabi created a whole encyclopedic system, where in his writings he considered such concepts as truth, logic and morality. In his philosophical reflections, al-Farabi touched on all aspects of human life. The importance of the work and the importance of the activities of Abu Nasr al-Farabi in the modern world is evidenced by the great attention paid to the study of his rich scientific heritage.

Key words: Al-Farabi, ancient Greek philosophy, Aristotle, philosophical system, God, man, happiness.

\author{
Яшар Айдынлы \\ УАудаг университеті Бусра қ., Түркия, E-mail: yasaraydinli@hotmail.com \\ Фараби және қазіргі заман
}

Эсседе ұлы ойшыл және философ әл-Фарабидің этикалық және философиялық ойтолғаныстарына арналған. Әл-Фарабилің философиялық жүйесі Құлай, адам әлемі, сонымен қатар адамның Әлемлегі орнына байланысты мәселелерге қатысты. Әл-Фарабидің философиялық ой-толғаныстарының қалыптасуына ежелгі грек философиясы, атап айтқанда, Аристотель еңбектерінің әсері зор болды. Әл-Фараби өзінің еңбектерінде шындық, могика және мораль туралы мәселелерді қарастыру арқылы біртұтас энциклопедиялық жүйе қалыптастырАы. Әл-Фараби өзінің шығармашылығында аАам болмысының, өмірінің барлық қырларына назар аударды. Қазіргі замандағы Әл-Фарабилің еңбектері мен шығармашылығының маңыздылығы оның ұрпақтарға қалдырған бай ғылыми мұрасын зерттеуге деген ерекше назар аударылуында.

Түйін сөздер: Әл-Фараби, ежелгі грек философиясы, Аристотель, философиялық жүйе, Құдай, адам, бақыт.

\author{
Яшар Айдынлы \\ Университета Улудаг, Турция, г. Бусра, e-mail: yasaraydinli@hotmail.com \\ Фараби и современный мир
}

В эссе рассматриваются этические и философские воззрения великого мыслителя и философа аль-Фараби. Философрская система, созданная аль-Фараби, касается основных проблем, связанных с вопросами Бога, вселенной и человека, а также места человека во Вселенной. На формирование философского мышления аль-Фараби повлияла Аревнегреческая философия, в частности, труды Аристотеля. А^ь-Фараби была создана целая энциклопедическая система, гАе в своих трудах он рассматривал такие понятия, как правда, ^огика и мора^ь. В своих философрских размышлениях аль-Фараби затрагивал все аспекты жизни человека. О значении трудов и важности деятельности Абу Насра аль-Фараби в современном мире свидетельствует огромное внимание, которое уделяется изучению его богатого научного наследия.

Кмючевые слова: аль-Фараби, древнегреческая философия, Аристотель, философская система, Бог, человек, счастье. 


\section{Essay}

First of all, I want to express my thanks. At first to the Republic of Kazakhstan, Kazakhs and especially Al-Farabi Kazakh National University. This is because, above all, it is the only institution in the world that keeps alive name of Farabi at the highest level. The name and the institution that is named after both are great. This is a very important privilege. Therefore, on behalf of the TurkishIslamic world, I express my thanks and gratitude. I would also like to express my gratitude for being invited as a part of Farabi research and thank very much the authorities.

What fascinated me during the 15 days I spent in Almaty five years ago was the deep and widespread interest in Farabi. There is a deep interest in other places, too. As a matter of fact, we see that Farabi has been rediscovered all over the world that has been educated especially in the last 40-50 years and is a subject of great interest. Of course, I also add Turkey. In the last few years in Turkey, a large number of Master's and Doctoral theses and many articles have been written about Farabi. Not only in Turkey, we know that intensive work done in Europe, America and in the part of the Middle East. Farabi's works are translated into the world languages again and more meticulously. Therefore, Farabi remains the focus of high interest in the scientific-academic context.

Certainly, studies about our philosopher are continuing in Kazakhstan. But what makes Kazakhstan different is the prevalence of interest in Farabi. What I see here and watch with great pleasure is that Farabi has become a social value and penetrates every part of society and every aspect of life. I personally care about this and hope that this approach will spread in all Islamic societies. Because there are opportunities to lead a person, a society, a country to the safety in Farabi philosophy, there is a very strong path between Farabi and the right way.

Farabi is not only one of the leading thinkers of the Turkish-Islamic world, but also of the history of human thought. The fact that he is named as "second teacher" in the history of philosophy is a proof of this. The lights reflected from his philosophy continue to illuminate humanity since the $10^{\text {th }}$ century when he passed away.

We can say that Farabi is the first philosopher in the Islamic world who discuss the intellectual problems of his culture in line with the demands of philosophical thought and express them in a coherent structure. The philosophical system established by
Farabi is concerned with the main problems of God, the universe and the human being in the cultural atmosphere in which he was born and developed, while he embodies the intellectual sensibilities of the Greek philosophy tradition. Therefore, it is possible to state that the attempt to analyze Farabi's philosophical system requires a two-way thinking movement. The first includes references to the ancient philosophy of this system, and the second, and perhaps more important, its references to the present situation and future directions of the local Islamic environment. So what does he say and show today to us, who is trying to get to know him, to learn his philosophy?

Of course, it is not possible to take the system of a tenth century philosopher Farabi and to implement it as such to the present day, because thousand years have passed. But there is something in him that does not fall from value, that was not wear out, and that it will never wear out, and that is the Farabi spirit. This spirit expresses the right view, the right attitude and the right approach to creation, life, and the world in which we live.

Farabi started from human and human mind. It is this point of start that confronts him with the science and philosophy of the Ancient world, which is the culture based on reason. He presented us with a very good example of this approach in his eightyyear lifetime, which started from Farab and ended in Damascus. This lifetime is literally a quest for truth. This search does not ignore pagan, Jewish, Christian and Muslim, but it surely observes them, searching for the human being as an intelligent being. Yes, a life that pursues truth; So what is the truth, what kind of nature it has, with what we can recognize it, how can we understand that what we reach is truth? Farabi's answer to these questions, which are the basis of all kinds of scientific and philosophical research, is very clear: We know the truth not with faith, mystical intuition, meditation, or anything else, but with reason; but with reason working under the control of logic. Therefore, logic, as a method of laws / rules, which prevents us from misrepresenting in our thinking and directs us to the right, must come first. Regardless of its content, one can believe in everything, but there is only one way to know the thing exactly, and that is logic. That's the first thing Farabi teaches us. In other words, this is the way to obtain the truth of science and to have theoretical virtues.

In his book The Census of Sciences, Farabi describes the art of logic, relating to the object of thinking, that direct the mind to the truth and prevent it from falling into the wrong, and accepts 
it as the sole criterion and instrument of correct thinking. According to him, without this tool, it is not possible for the mind to work correctly, that is, to move towards the right and to stay away from the wrong, nor can it be possible to determine the correctness and inaccuracy of the views expressed by others. In this context, Fârâbî speaks of a three-dimensional function of logic which he sees as an art that gives the laws of right thinking in general. First, thanks to the laws of this art, we acquire the power to distinguish between right and wrong, and direct our thinking towards the right, away from the wrong. Secondly, through these laws, we have the opportunity to determine the accuracy or inaccuracy of the opinions expressed by others in words or texts, and to show precisely why one view is correct and why other is wrong. Thirdly, through the laws of logic, we have the opportunity to control the criticisms directed to our own views and to show the correctness of the right and the wrongness of the wrong and reveal the reasons. Therefore, the art of logic gives man a clarity of mind and saves him from contradiction, inconsistency, and all kinds of confusion. That is to say, by confidently determining which of the contradictory views are true and which is wrong, we can avoid mistakes by confusing the truth to the wrong, and know the reason for the truth and the reason for the wrong. Therefore, logic is a tool that conveys definite knowledge in all theoretical and practical sciences, and there is no other way of achieving true certainty in relation to any intended knowledge.

Farabi's emphasis on the necessity of knowing logic must be considered not only in terms of the clarity of the mind of the individual, but also in terms of the clarity of the social mind. Because it is possible to reach reliable information in thoughtbased sciences only by using an objective control tool that distinguishes right from wrong, which is logic. This is the main reason why Fārabi considered logic as a matter of mentality, and he made efforts to establish a logic-based scientific mentality in the field of rational sciences. The person who best understood the call of Farabi, who urged his own society to think logically, was Ghazali, who made logic the requirement of reliable knowledge.

The second thing that Farabi teaches us is the virtue of living, morality. Because knowledge alone does not have the power to make us happy. A moral stance and living supported by knowledge and wisdom is necessary in the face of world and worldly things, and Farabi's life is a good example of this. Our sources portray him as a scholar and a symbol of morality, when evaluate our philosopher's view of the world and material things. "He was the most satisfied of people against the world". He was cautious and blind to the world's material values, authority, money, property, food and drink, clothing and worldly blessings in general. "He didn't give even a little value to appearance, home and material gain". People have always seen him in the same dresses and in standard Turkish clothing. His higher authority in knowledge, wisdom and education did not lead to a change in his way of living.

Doesn't it have any importance to hold property, money and worldly blessings in general for human life? We need to specify that Farabi is not a mystic and the idea of "abandonment of world" is not the part of his thought. Farabi not only values every kind of things that makes human life easier, but also says that it is necessary. Because one cannot live alone and cannot realize him or his own abilities in an environment that does not have sufficient financial equipment. Farabi says that the socialpolitical conditions necessary for happiness can only be found in a social organization that has the character of a city. Therefore, worldly goodness is also necessary for the spiritual development and rise of man. What Farabi is absolutely opposed to is the determination of worldly goodness, pleasure, wealth, honor and others, as the purpose and ultimate goal of life. Because the ultimate goal of man is the happiness of the afterlife. 